\title{
THE MAGURA CAVE IN NORTH-WESTERN BULGARIA: EXPLORING VISITATION AND SPELEOTOURISM POTENTIAL
}

\author{
Aleksandar Antić ${ }^{A}$ \\ Received: May 31, 2020 | Accepted: September 23, 2020 \\ DOI: 10.5937/ZbDght2002163A
}

\begin{abstract}
Speleotourism implies visiting caves and respecting geomorphological values. A visit to the caves must include certain rules of conduct and implementation of geoethical values to achieve sustainable speleotourism development. This paper investigates the tourist traffic of an authentic cave in northwestern Bulgaria, the Magura Cave, which is a speleological object with exceptional potential for the development of speleotourism. The explored cave includes unique examples of cave paintings and imposing historical values. The research methodology mainly included descriptive analysis of data obtained by the administrative staff of the Municipality of Belogradchik. The data of tourist visits are presented in tables and graphs. The research results indicate the current state and potential prospects for the development of speleotourism in the Magura Cave. Moreover, the paper presents measures for more effective development of speleotourism, which are of special importance for organizational and cave management structures.
\end{abstract}

Keywords: Speleotourism, Magura Cave, tourist traffic, forecast.

\section{INTRODUCTION}

The search for new experiences has always been a trend among tourists (Vespestad et al., 2019; Rogerson, 2020; Pellešová, 2020). Visiting the natural environment and tourist affirmation of georesources is becoming increasingly important (Escorihuela and Dowling, 2015; Gordon, 2018; Rivero et al., 2019), especially in the field of speleotourism (Tičar et al., 2018; Tomić et al., 2019; Antić and Tomić 2019; Antić et al., 2019). Cave visitation includes exploration of inner caves and cave areas, studying a cave or its surroundings from geological, cultural, historical, archaeological, botanical and environmental educational viewpoints. Furthermore, enjoying recreational opportunities

A Department of Geography, Tourism and Hotel Management, Faculty of Sciences, University of Novi Sad, Trg Dositeja Obradovića 3, 21000 Novi Sad, Serbia. Corresponding author: a.anticg94@gmail.com 
in cave areas surrounded by limestone terrain and water valleys have proven to be a favourable complementary aspect of speleotourism (Kim et al., 2008). In addition, speleological geoheritage sites can generate employment and new economic activities, especially in rural regions in need of new or additional sources of income (El Wartiti et al., 2009; Farsani et al., 2011).

This is very important for underdeveloped areas in Southeast Europe, which lack significant investment projects and effective economic development (Uvalić, 2001). Geotourism and speleotourism can play a major role in economic revitalization in this region, as these types of tourism place a focus on the rich natural resources stationed in the area. Attracting (geo)tourists encompasses complex groups of tasks, but also a crucial necessity that is an indicator of development and prosperity (Ríos-Reyes et al., 2018; Köroğlu and Kandemir, 2019; Štrba et al., 2020; Vukoičić et al., 2020). Although speleotourism is not sufficiently developed, it is necessary to explore all factors that can reveal ways to make the most of speleotourism potentials in order to achieve socio-economic, sustainable and geoethical values.

The study of tourist visits implies an important research endeavour, which has been the subject of many multidisciplinary explorations (Cahill et al., 2008; Wong and Zhao, 2016; Schliephack and Dickinson, 2017; Avgeli et al., 2019; Joo et al., 2019). The geoconservation aspect of caves and speleotourism must be a priority of management and organizational structures. For this reason, visits should be adjusted to the appropriate carrying capacity obtained by measuring the presence of carbon dioxide, air temperature and humidity, before, during and after tourist visits (Lobo, 2015).

However, in the case of speleotourism research, tourist visitation has not been sufficiently explored. In this paper, the research focus is placed on the tourist traffic of the speleological object in northwestern Bulgaria, the Magura Cave. The main goal of the research is to analyze the number of visitors in this cave, and to determine possible guidelines for further speleotourism development. The primary research questions relate to the current state and prospects of speleotourism development in Magura Cave:

1. To what extent has the current speleotourism been developed (current state of speleotourism)?

2. What measures should be taken in order to place this cave on a higher position of the regional tourist market (future perspectives of speleotourism)?

Also, the activities that should be implemented in the tourist offer of the cave were presented, so that the tourist would have a better experience and repeat the visit to this speleo-archaeological geosite.

\section{STUDY AREA}

Regionally, Magura Cave is located in the western part of the Balkan Mountains - a range which spans from the north-west to the central Bulgaria, the Thracian plain lying to the south-east of the range, and the plain in turn fringed by the Rhodope Mountain range at its western edge (Figure 1). The River Danube lies about $25 \mathrm{~km}$ to the north-east 

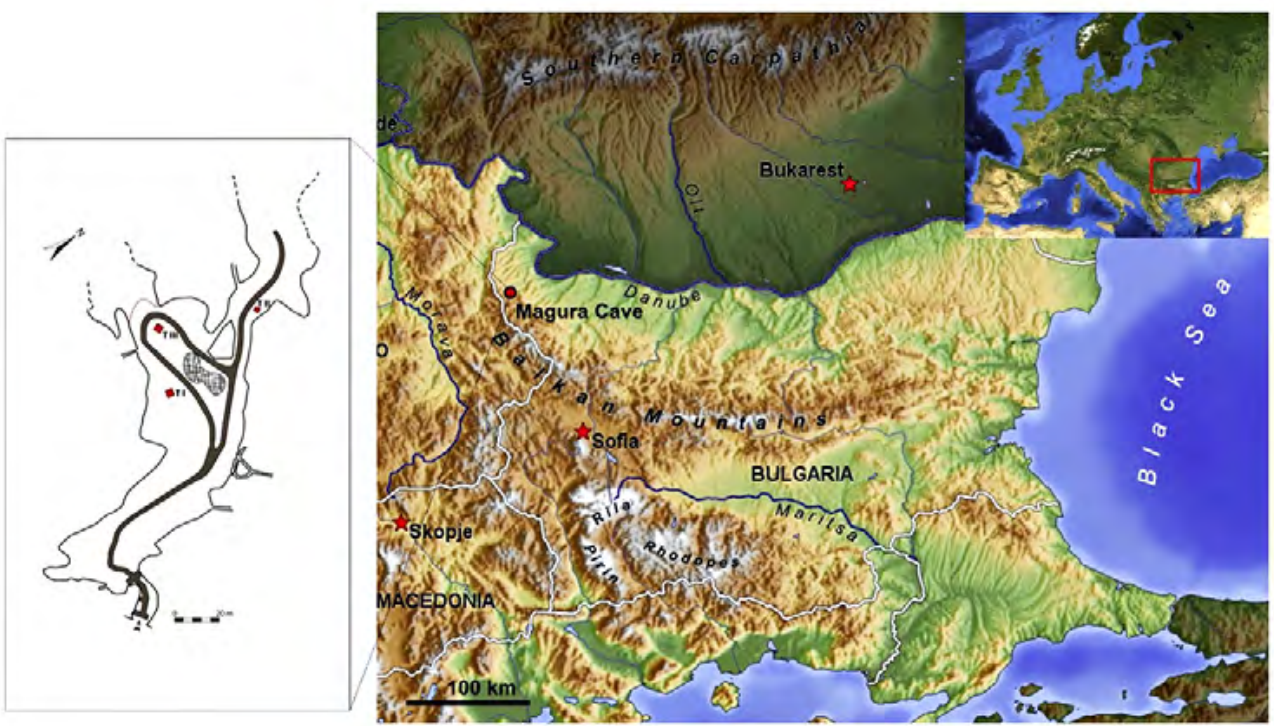

Figure 1. The plan and location of the Magura Cave

Source: (Ivanova et al., 2016)

of Magura, the Danube valley linking Central Europe and the Balkans with the Black sea coastal zone. Magura Cave is located on Rabisha Hill (461 m above sea level). It is 25 $\mathrm{km}$ north-west of the town of Belogradchik and $35 \mathrm{~km}$ south of the city of Vidin (Ivanova et al., 2016).

The proximity to the Serbian border enables this geosite to join the regional tourism development, and to enrich the geotourism and speleotourism offers of Bulgaria and Serbia (Carpathian-Balkan region).

The first information about the cave appeared in the 1920s and 1930s in the publications of Mikov (1927) and Filkov (1936/7). The first systematic archaeological explorations in the cave were undertaken in 1961 in the entrance ("Triumphant") hall, at around $20 \mathrm{~m}$ from the main entrance (Dzhambazov and Katincharov, 1961). The length of this hall is $120 \mathrm{~m}$, width $58 \mathrm{~m}$ and the highest point on its ceiling is $28 \mathrm{~m}$. Investigations have revealed settlements in the cave dating back to the Neolithic, Chalcolithic and Bronze Age periods (Ivanova et al., 2016).

Magura Cave is now open to the public (Figure 2), with a path descending and winding through the "Triumphant" hall, a side gallery of which has been converted into a commercial winery. In the construction process, a large quantity of sediment was removed, but some bones (mainly from Ursus spelaeus s. lato) were taken for the collection of the Vidin Museum. Among these, several human bones were also found, but are now known to be from the Bronze Age. The cave has become famous for its prehistoric drawings in the so-called "Painting Gallery", located in a side branch off the main gallery around $300 \mathrm{~m}$ into the cave, which are established to be from the Chalcolithic and Bronze Ages (fifth to third millenia BC). At its entrance there is an image of a galloping horse, very different to the Holocene drawings and the only drawing made with a mate- 
A

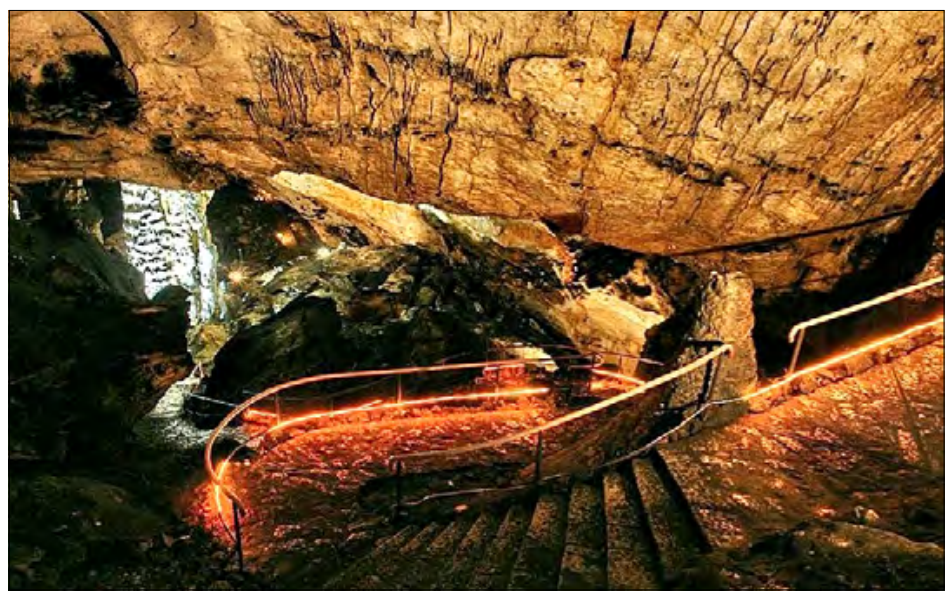

B

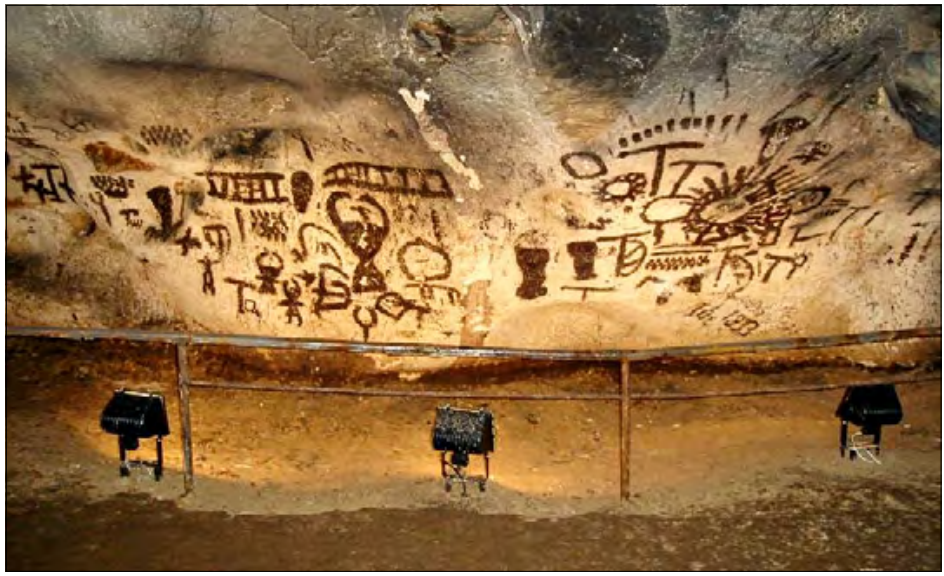

C

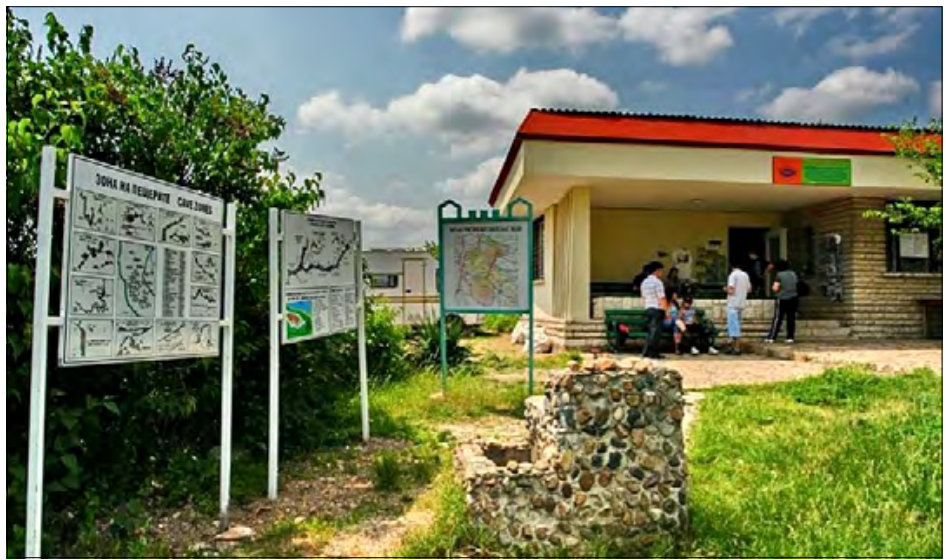

Figure 2. Magura Cave; (A) Pedestrian track in the Cave (Source: www.ilovebulgaria.eu/ en/magura-cave/); (B) Cave art (Source: www.easytouristguides.com/tour/tour-bulgariadiscover-north-western-bulgaria/); (C) Information Center of the Magura Cave (Source: www. ilovebulgaria.eu/en/magura-cave/) 
rial other than guano; it is in poor condition, but is considered to be Palaeolithic/Mesolithic in style (Stoytchev, 1994; Ivanova et al., 2016).

\section{METHODOLOGY}

In the phase of defining the theoretical framework of the paper, a bibliographic-speculative method was used, while the processing and interpretation of the results was done using the descriptive method. The main methodological approach is based on the analysis of tourist traffic data of Magura Cave, in the period from January 2012 to December 2019. Descriptive analysis also included the use of tables and graphs, in order to more effectively identify the similarities and differences of the data between the observed periods. Access to the data was provided by the administrative staff of the Municipality of Belogradchik.

\section{RESULTS AND DISCUSSION}

The first observed period implies the year of 2012 (Table 1). In this period, the largest number of visitors to the Magura cave visited the cave at the very beginning of the summer season (4,517 visitors in April) and in August (5,348 visitors). With the exception of July (4,275 visitors), there were less than 4,000 visits in all other months. September can also be seen as an exception, because the cave was visited by 3,990 visitors at that time. In any case, this is a rather small number for an attractive tourist destination, such as Magura Cave. It should be noted that in all observed years, winter periods include the lowest number of visits. Also, there are significantly more domestic tourists than foreign tourists. This fact is most adequately reflected in the total number of domestic and foreign tourists. During 2012, the Magura Cave was visited by 27,340 domestic tourists and 2,492 foreign tourists. This large and significant difference did not change until 2019, which is a negative element in the speleotourism development of Magura Cave. That is why it is necessary to elaborate much more on marketing strategies and propaganda goals.

The following year (Table 2), 1,323 fewer tourists visited the cave. Therefore, the work of the management structure in 2012 can be considered a failure, because not only the growth of tourist traffic was lacking, but the decline exceeded 1,000 visitors, which is not a positive outcome. The most advanced months for tourist traffic in Magura Cave are the same this year as in 2012. In April, the cave was visited by 4,947 visitors, and in August as many as 5,190. The trend that brings a large number of tourists at the beginning of the summer season continues, but also in August when a large number of people take vacations, due to ideal temperature conditions. Also, the big difference between domestic and foreign tourists continues. The total number of foreign tourists needs to be much higher and achieving this should be the main goal of the Magura Cave management team. 
Table 1. Visitors in the Magura Cave in 2012

\begin{tabular}{|c|c|c|c|}
\hline Month/Year & Domestic/Foreign tourists & Amount of visitors & Total \\
\hline \multirow{2}{*}{ January 2012} & Domestic & 172 & \multirow{2}{*}{206} \\
\hline & Foreign & 34 & \\
\hline \multirow{2}{*}{ February 2012.} & Domestic & 30 & \multirow{2}{*}{31} \\
\hline & Foreign & 1 & \\
\hline \multirow{2}{*}{ March 2012} & Domestic & 410 & \multirow{2}{*}{490} \\
\hline & Foreign & 80 & \\
\hline \multirow{2}{*}{ April 2012.} & Domestic & 4,300 & \multirow{2}{*}{4,517} \\
\hline & Foreign & 217 & \\
\hline \multirow{2}{*}{ May 2012.} & Domestic & 2,914 & \multirow{2}{*}{3,272} \\
\hline & Foreign & 358 & \\
\hline \multirow{2}{*}{ June 2012} & Domestic & 3,646 & \multirow{2}{*}{3,972} \\
\hline & Foreign & 326 & \\
\hline \multirow{2}{*}{ July 2012} & Domestic & 3,888 & \multirow{2}{*}{4,275} \\
\hline & Foreign & 387 & \\
\hline \multirow{2}{*}{ August 2012} & Domestic & 4,747 & \multirow{2}{*}{5,348} \\
\hline & Foreign & 601 & \\
\hline \multirow{2}{*}{ September 2012} & Domestic & 3,778 & \multirow{2}{*}{3,990} \\
\hline & Foreign & 212 & \\
\hline \multirow{2}{*}{ October 2012} & Domestic & 2,114 & \multirow{2}{*}{2,304} \\
\hline & Foreign & 190 & \\
\hline \multirow{2}{*}{ November 2012} & Domestic & 1,098 & \multirow{2}{*}{1,178} \\
\hline & Foreign & 80 & \\
\hline \multirow{2}{*}{ December 2012} & Domestic & 243 & \multirow{2}{*}{249} \\
\hline & Foreign & 6 & \\
\hline \multirow{2}{*}{ Total 2012} & Domestic & 27,340 & \multirow{2}{*}{29,832} \\
\hline & Foreign & 2,492 & \\
\hline
\end{tabular}

Table 2. Visitors in the Magura Cave in 2013

\begin{tabular}{|l|l|c|c|}
\hline Month/Year & Domestic/Foreign tourists & Amount of visitors & Total \\
\hline \multirow{2}{*}{ January 2013 } & Domestic & 98 & \multirow{2}{*}{111} \\
\cline { 2 - 3 } & Foreign & 13 & \multirow{2}{*}{258} \\
\hline \multirow{2}{*}{ February 2013 } & Domestic & 190 & \multirow{2}{*}{840} \\
\cline { 2 - 3 } & Foreign & 68 & \multirow{2}{*}{4,947} \\
\hline \multirow{2}{*}{ March 2013 } & Domestic & 738 & \\
\cline { 2 - 4 } & Foreign & 102 & \\
\hline
\end{tabular}




\begin{tabular}{|c|c|c|c|}
\hline Month/Year & Domestic/Foreign tourists & Amount of visitors & Total \\
\hline \multirow{2}{*}{ May 2013} & Domestic & 2,081 & \multirow{2}{*}{2,308} \\
\hline & Foreign & 227 & \\
\hline \multirow{2}{*}{ June 2013} & Domestic & 2,952 & \multirow{2}{*}{3,451} \\
\hline & Foreign & 499 & \\
\hline \multirow{2}{*}{ July 2013} & Domestic & 3,263 & \multirow{2}{*}{3,723} \\
\hline & Foreign & 460 & \\
\hline \multirow{2}{*}{ August 2013} & Domestic & 4,600 & \multirow{2}{*}{5,190} \\
\hline & Foreign & 590 & \\
\hline \multirow{2}{*}{ September 2013} & Domestic & 3,391 & \multirow{2}{*}{3,724} \\
\hline & Foreign & 333 & \\
\hline \multirow{2}{*}{ October 2013} & Domestic & 1,998 & \multirow{2}{*}{2,276} \\
\hline & Foreign & 278 & \\
\hline \multirow{2}{*}{ November 2013} & Domestic & 1,229 & \multirow{2}{*}{1,357} \\
\hline & Foreign & 128 & \\
\hline \multirow{2}{*}{ December 2013} & Domestic & 302 & \multirow{2}{*}{324} \\
\hline & Foreign & 22 & \\
\hline \multirow{2}{*}{ Total 2013} & Domestic & 25,458 & \multirow{2}{*}{28,509} \\
\hline & Foreign & 3,051 & \\
\hline
\end{tabular}

In 2014, there was a significant decline in tourist traffic (Table 3). As many as 7,140 fewer tourists visited the cave compared to 2012 and 5,817 fewer tourists visited the cave compared to 2013. This example clearly shows the negative effect of all direct and indirect tourist factors that influence the speleotourism of Magura Cave. Although the decline is much higher compared to the decline from the previous year, in August 2014, the cave was visited by 4,813 tourists. This can be taken as a positive result compared to all other months in this year. Certainly, in 2014, the speleotouristic significance of the cave further decreased.

In the next year, the tourist traffic of Magura Cave is improving (Table 4). In 2015, the cave was visited by more tourists compared to the previous two years, but not compared to 2012. This growth of tourist traffic is a positive sign, which gives hope for the future development of speleotourism, but not the certainty that there will be unconditional business success. A lot of effort and significant business ventures need to be undertaken in order for the cave to be visited by a significantly larger number of tourists. Table 4 clearly indicates that August and September are the months in which the largest number of tourists visited the cave. In September, the cave was visited by as many as 6,848 tourists, which is the largest number of visitors since the beginning of the observed period. 
Table 3. Visitors in the Magura Cave in 2014

\begin{tabular}{|c|c|c|c|}
\hline Month/Year & Domestic/Foreign tourists & Amount of visitors & Total \\
\hline \multirow{2}{*}{ January 2014} & Domestic & 169 & \multirow{2}{*}{183} \\
\hline & Foreign & 14 & \\
\hline \multirow{2}{*}{ February 2014} & Domestic & 203 & \multirow{2}{*}{231} \\
\hline & Foreign & 28 & \\
\hline \multirow{2}{*}{ March 2014} & Domestic & 928 & \multirow{2}{*}{1,073} \\
\hline & Foreign & 145 & \\
\hline \multirow{2}{*}{ April 2014} & Domestic & 1,929 & \multirow{2}{*}{2,365} \\
\hline & Foreign & 436 & \\
\hline \multirow{2}{*}{ May 2014} & Domestic & 1,981 & \multirow{2}{*}{2,418} \\
\hline & Foreign & 437 & \\
\hline \multirow{2}{*}{ June 2014} & Domestic & 2,953 & \multirow{2}{*}{3,333} \\
\hline & Foreign & 380 & \\
\hline \multirow{2}{*}{ July 2014} & Domestic & 3,157 & \multirow{2}{*}{3,619} \\
\hline & Foreign & 462 & \\
\hline \multirow{2}{*}{ August 2014} & Domestic & 4,089 & \multirow{2}{*}{4,813} \\
\hline & Foreign & 724 & \\
\hline \multirow{2}{*}{ September 2014} & Domestic & 2,205 & \multirow{2}{*}{2,483} \\
\hline & Foreign & 278 & \\
\hline \multirow{2}{*}{ October 2014} & Domestic & 1,221 & \multirow{2}{*}{1,362} \\
\hline & Foreign & 141 & \\
\hline \multirow{2}{*}{ November 2014} & Domestic & 541 & \multirow{2}{*}{663} \\
\hline & Foreign & 122 & \\
\hline \multirow{2}{*}{ December 2014} & Domestic & 141 & \multirow{2}{*}{149} \\
\hline & Foreign & 8 & \\
\hline \multirow{2}{*}{ Total 2014} & Domestic & 19,517 & \multirow{2}{*}{22,692} \\
\hline & Foreign & 3,175 & \\
\hline
\end{tabular}

After 2015, the number of visits to Magura Cave rises to over 30,000 visits. This is a positive outcome that has partial business results, as the cave management offer has been modernized since this year. A souvenir shop and a restaurant have been opened and the access to the geosite has been additionally arranged. All these parameters represent minimal effort, which show certain results. However, progress is still low and the potential of the cave is not reaching its maximum. Moreover, the number of foreign tourists decreased significantly compared to the previous year. August and September are still the periods in which the largest number of visits prevails, while the winter months are in constant stagnation of tourist traffic.

The rising trend of tourist traffic partially continues in 2017. The total number of tourists is lower than the previous year by 227 visitors. April, August and September are 
again the months with the highest number of foreign and domestic visits, while only in January, February and December, the cave is visited by less than 1,000 tourists.

Table 4. Visitors in the Magura Cave in 2015

\begin{tabular}{|c|c|c|c|}
\hline Month/Year & Domestic/Foreign tourists & Amount of visitors & Total \\
\hline \multirow{2}{*}{ January 2015} & Domestic & 124 & \multirow{2}{*}{130} \\
\hline & Foreign & 6 & \\
\hline \multirow{2}{*}{ February 2015} & Domestic & 159 & \multirow{2}{*}{241} \\
\hline & Foreign & 82 & \\
\hline \multirow{2}{*}{ March 2015} & Domestic & 718 & \multirow{2}{*}{821} \\
\hline & Foreign & 103 & \\
\hline \multirow{2}{*}{ April 2015} & Domestic & 1,836 & \multirow{2}{*}{1,972} \\
\hline & Foreign & 136 & \\
\hline \multirow{2}{*}{ May 2015} & Domestic & 3,157 & \multirow{2}{*}{3,519} \\
\hline & Foreign & 362 & \\
\hline \multirow{2}{*}{ June 2015} & Domestic & 3,017 & \multirow{2}{*}{3,452} \\
\hline & Foreign & 435 & \\
\hline \multirow{2}{*}{ July 2015} & Domestic & 2,807 & \multirow{2}{*}{3,337} \\
\hline & Foreign & 530 & \\
\hline \multirow{2}{*}{ August 2015} & Domestic & 5,213 & \multirow{2}{*}{5,991} \\
\hline & Foreign & 778 & \\
\hline \multirow{2}{*}{ September 2015} & Domestic & 4,024 & \multirow{2}{*}{6,848} \\
\hline & Foreign & 2,824 & \\
\hline \multirow{2}{*}{ October 2015} & Domestic & 1,584 & \multirow{2}{*}{1,688} \\
\hline & Foreign & 104 & \\
\hline \multirow{2}{*}{ November 2015} & Domestic & 948 & \multirow{2}{*}{1,055} \\
\hline & Foreign & 107 & \\
\hline \multirow{2}{*}{ December 2015} & Domestic & 308 & \multirow{2}{*}{335} \\
\hline & Foreign & 27 & \\
\hline \multirow{2}{*}{ Total 2015} & Domestic & 23,895 & \multirow{2}{*}{29,389} \\
\hline & Foreign & 5,494 & \\
\hline
\end{tabular}

Table 5. Visitors in the Magura Cave in 2016

\begin{tabular}{|l|l|c|c|}
\hline \multirow{2}{*}{ Month/Year } & Domestic/Foreign tourists & Amount of visitors & Total \\
\hline \multirow{2}{*}{ February 2016 2016} & Domestic & 120 & \multirow{2}{*}{131} \\
\cline { 2 - 3 } & Foreign & 11 & \multirow{2}{*}{351} \\
\cline { 2 - 3 } & Domestic & 304 & \\
\hline
\end{tabular}




\begin{tabular}{|c|c|c|c|}
\hline Month/Year & Domestic/Foreign tourists & Amount of visitors & Total \\
\hline \multirow{2}{*}{ March 2016} & Domestic & 1,014 & \multirow{2}{*}{1,089} \\
\hline & Foreign & 75 & \\
\hline \multirow{2}{*}{ April 2016} & Domestic & 3,227 & \multirow{2}{*}{3,429} \\
\hline & Foreign & 202 & \\
\hline \multirow{2}{*}{ May 2016} & Domestic & 3,914 & \multirow{2}{*}{4,229} \\
\hline & Foreign & 315 & \\
\hline \multirow{2}{*}{ June 2016} & Domestic & 3,139 & \multirow{2}{*}{3,447} \\
\hline & Foreign & 308 & \\
\hline \multirow{2}{*}{ July 2016} & Domestic & 3,826 & \multirow{2}{*}{4,464} \\
\hline & Foreign & 638 & \\
\hline \multirow{2}{*}{ August 2016} & Domestic & 5,245 & \multirow{2}{*}{5,888} \\
\hline & Foreign & 643 & \\
\hline \multirow{2}{*}{ September 2016} & Domestic & 5,139 & \multirow{2}{*}{5,518} \\
\hline & Foreign & 379 & \\
\hline \multirow{2}{*}{ October 2016} & Domestic & 2,118 & \multirow{2}{*}{2,335} \\
\hline & Foreign & 217 & \\
\hline \multirow{2}{*}{ November 2016} & Domestic & 530 & \multirow{2}{*}{616} \\
\hline & Foreign & 86 & \\
\hline \multirow{2}{*}{ December 2016} & Domestic & 327 & \multirow{2}{*}{378} \\
\hline & Foreign & 51 & \\
\hline \multirow{2}{*}{ Total 2016} & Domestic & 28,903 & \multirow{2}{*}{31,875} \\
\hline & Foreign & 2,972 & \\
\hline
\end{tabular}

Marketing team needs to improve the strategies and business approaches, due to the constant decrease of foreign tourist visitations.

Table 6. Visitors in the Magura Cave in 2017

\begin{tabular}{|l|l|c|c|}
\hline Month/Year & Domestic/Foreign tourists & Amount of visitors & Total \\
\hline \multirow{3}{*}{ January 2017 } & Domestic & 41 & \multirow{2}{*}{62} \\
\cline { 2 - 3 } & Foreign & 21 & \multirow{2}{*}{181} \\
\hline \multirow{2}{*}{ February 2017 } & Domestic & 171 & \multirow{2}{*}{1,472} \\
\cline { 2 - 3 } & Foreign & 10 & \multirow{2}{*}{4,225} \\
\hline \multirow{2}{*}{ April 2017 2017} & Domestic & 1,305 & \multirow{2}{*}{3,196} \\
\cline { 2 - 3 } & Foreign & 3,603 & \\
\hline \multirow{2}{*}{ May 2017 } & Domestic & 622 & 2,939 \\
\cline { 2 - 3 } & Foreign & 257 & \\
\cline { 2 - 4 } & Domestic & & \\
\cline { 2 - 3 } & Foreign & & \\
\hline
\end{tabular}




\begin{tabular}{|c|c|c|c|}
\hline Month/Year & Domestic/Foreign tourists & Amount of visitors & Total \\
\hline \multirow{2}{*}{ June 2017} & Domestic & 3,224 & \multirow{2}{*}{3,739} \\
\hline & Foreign & 515 & \\
\hline \multirow{2}{*}{ July 2017} & Domestic & 3,251 & \multirow{2}{*}{3,807} \\
\hline & Foreign & 556 & \\
\hline \multirow{2}{*}{ August 2017} & Domestic & 5,180 & \multirow{2}{*}{5,953} \\
\hline & Foreign & 773 & \\
\hline \multirow{2}{*}{ September 2017} & Domestic & 4,781 & \multirow{2}{*}{5,388} \\
\hline & Foreign & 607 & \\
\hline \multirow{2}{*}{ October 2017} & Domestic & 1,850 & \multirow{2}{*}{2,063} \\
\hline & Foreign & 213 & \\
\hline \multirow{2}{*}{ November 2017} & Domestic & 929 & \multirow{2}{*}{1,055} \\
\hline & Foreign & 126 & \\
\hline \multirow{2}{*}{ December 2017} & Domestic & 459 & \multirow{2}{*}{507} \\
\hline & Foreign & 48 & \\
\hline \multirow{2}{*}{ Total 2017} & Domestic & 27,733 & \multirow{2}{*}{31,648} \\
\hline & Foreign & 3,915 & \\
\hline
\end{tabular}

Table 7. Visitors in the Magura Cave in 2018

\begin{tabular}{|c|c|c|c|}
\hline Month/Year & Domestic/Foreign tourists & Amount of visitors & Total \\
\hline \multirow{2}{*}{ January 2018} & Domestic & 224 & \multirow{2}{*}{239} \\
\hline & Foreign & 15 & \\
\hline \multirow{2}{*}{ February 2018} & Domestic & 341 & \multirow{2}{*}{396} \\
\hline & Foreign & 55 & \\
\hline \multirow{2}{*}{ March 2018} & Domestic & 659 & \multirow{2}{*}{853} \\
\hline & Foreign & 194 & \\
\hline \multirow{2}{*}{ April 2018} & Domestic & 3,047 & \multirow{2}{*}{3,896} \\
\hline & Foreign & 849 & \\
\hline \multirow{2}{*}{ May 2018} & Domestic & 4,273 & \multirow{2}{*}{5,189} \\
\hline & Foreign & 916 & \\
\hline \multirow{2}{*}{ June 2018} & Domestic & 3,610 & \multirow{2}{*}{4,320} \\
\hline & Foreign & 710 & \\
\hline \multirow{2}{*}{ July 2018} & Domestic & 4,419 & \multirow{2}{*}{5,233} \\
\hline & Foreign & 814 & \\
\hline \multirow{2}{*}{ August 2018} & Domestic & 6,006 & \multirow{2}{*}{6,975} \\
\hline & Foreign & 969 & \\
\hline \multirow{2}{*}{ September 2018} & Domestic & 4,935 & \multirow{2}{*}{5,489} \\
\hline & Foreign & 554 & \\
\hline
\end{tabular}




\begin{tabular}{|l|l|c|c|}
\hline Month/Year & Domestic/Foreign tourists & Amount of visitors & Total \\
\hline \multirow{2}{*}{ October 2018 } & Domestic & 2,110 & \multirow{2}{*}{2,451} \\
\cline { 2 - 3 } & Foreign & 341 & \\
\hline \multirow{2}{*}{ November 2018 } & Domestic & 1,278 & \multirow{2}{*}{402} \\
\cline { 2 - 3 } & Foreign & 124 & \multirow{2}{*}{433} \\
\hline \multirow{2}{*}{ December 2018 } & Domestic & 384 & \multirow{2}{*}{36,876} \\
\cline { 2 - 3 } & Foreign & 49 & \\
\hline \multirow{2}{*}{ Total 2018 } & Domestic & 5,286 & \\
\cline { 2 - 4 } & Foreign & & \\
\hline
\end{tabular}

In 2018 , the cave was visited by the largest number of tourists $(36,876)$. This growth does not refer to a significant increase in tourist traffic. The cave was visited by 5,228 more tourists compared to the previous year, but given the level of attractiveness, especially speleo-archaeological complementarities of the geosite, the number of visits should exceed 50,000 visits in order for the work of management and organizational structures of Magura Cave to be considered a significant success. All significant european show caves include more then 50,000 visits per year and the Magure cave should be included in that group (Cigna and Burri, 2000; Cigna, 2016; Cigna, 2019).

Although the difference between the number of foreign and domestic tourists is large, in 2018 there was a modest growth of foreign tourists visitation, which can be taken into account when developing strategic plans for speleotourism development. The summer months are continuously dominated by the number of tourist visits. August is the month when by far the largest number of tourists visit the cave. Thus, it is necessary to organize a certain event program in that month, which can attract even more potential tourists.

The last observed year includes similar number of visits as previous years (Table 8). However, the number of foreign tourists has decreased, which further confirms the lack of a quality marketing program, that can more effectively influence the attraction of foreign tourists. The month of August is still the only period when the number of visits exceeds 6,000 , so it can be concluded that there is an evident business opportunity to use this for the promotion of speleotourism program. The last two observed years include data on tourist traffic that exceeds 36,000 visits, which is a success, but not to the extent that is sufficient for significant speleotouristic development.

Table 8. Visitors in the Magura Cave in 2019

\begin{tabular}{|l|l|c|c|}
\hline Month/Year & Domestic/Foreign tourists & Amount of visitors & Total \\
\hline \multirow{2}{*}{ January 2019 } & Domestic & 119 & \multirow{2}{*}{184} \\
\cline { 2 - 3 } & Foreign & 65 & \\
\hline \multirow{2}{*}{ February 2019 } & Domestic & 244 & \multirow{2}{*}{278} \\
\cline { 2 - 3 } & Foreign & 34 & \\
\hline
\end{tabular}




\begin{tabular}{|c|c|c|c|}
\hline Month/Year & Domestic/Foreign tourists & Amount of visitors & Total \\
\hline \multirow{2}{*}{ March 2019} & Domestic & 1,595 & \multirow{2}{*}{1,977} \\
\hline & Foreign & 382 & \\
\hline \multirow{2}{*}{ April 2019} & Domestic & 4,102 & \multirow{2}{*}{4,627} \\
\hline & Foreign & 525 & \\
\hline \multirow{2}{*}{ May 2019} & Domestic & 4,561 & \multirow{2}{*}{5,085} \\
\hline & Foreign & 524 & \\
\hline \multirow{2}{*}{ June 2019} & Domestic & 4,043 & \multirow{2}{*}{4,614} \\
\hline & Foreign & 571 & \\
\hline \multirow{2}{*}{ July 2019} & Domestic & 3,542 & \multirow{2}{*}{4,300} \\
\hline & Foreign & 758 & \\
\hline \multirow{2}{*}{ August 2019} & Domestic & 5,130 & \multirow{2}{*}{6,046} \\
\hline & Foreign & 916 & \\
\hline \multirow{2}{*}{ September 2019} & Domestic & 4,367 & \multirow{2}{*}{5,012} \\
\hline & Foreign & 645 & \\
\hline \multirow{2}{*}{ October 2019} & Domestic & 2,309 & \multirow{2}{*}{2,696} \\
\hline & Foreign & 387 & \\
\hline \multirow{2}{*}{ November 2019} & Domestic & 1,009 & \multirow{2}{*}{1,118} \\
\hline & Foreign & 109 & \\
\hline \multirow{2}{*}{ December 2019} & Domestic & 479 & \multirow{2}{*}{519} \\
\hline & Foreign & 40 & \\
\hline \multirow{2}{*}{ Total 2019} & Domestic & 31,500 & \multirow{2}{*}{36,456} \\
\hline & Foreign & 4,956 & \\
\hline
\end{tabular}

As shown in Figure 3. the highest total number of visits in Magura Cave occured in 2018, while the lowest number of visits occured in 2014. The highest number of foreign visits to the Magure Cave occured also in 2018, while the lowest number occured in 2012. Moreover, the highest number of domestic visits occured in 2019 and the lowest number in 2014. Therefore, the general conclusion from the main data is that 2018 and 2019 were the years with the most success, while the year 2014 represents the most ineffective period for the visitation numbers. The minimal efforts of arranging the speleotouristic area gave Magura cave a certain type of development that cannot be considered completely satisfactory, because the focus has not been established on the foreign market, ie attracting foreign tourists. The sustainability of the geosite relies exclusively on domestic tourists. This is one of the factors that needs to be revised by making an adequate balance between domestic and foreign tourist visits, without large differences in the visitation numbers. This is a difficult task, but certainly feasible and necessary. Also, creating an event program in the month of August, when the largest number of tourists visit the cave would provide an opportunity to attract many potential tourists. The marketing program must be improved, the cave website should be modernized and complementary sites should be promoted more efficiently. 


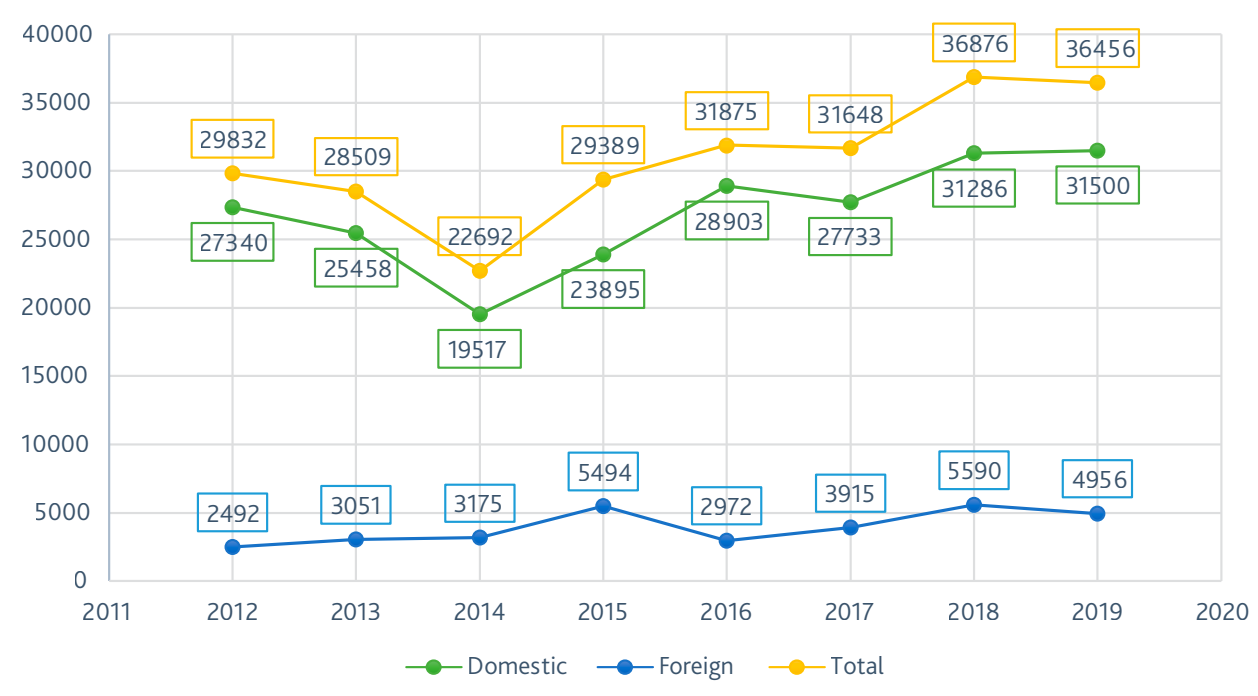

Figure 3. Domestic, foreign and total number of visitors (2012-2019)

Moreover, turning tourist potentials into sustainable and economically viable tourist values should be the primary goal of the cave management structures. With the implementation of the following business plans, the cave management can improve the speleotourism development of the Magura Cave:

- Modernization of the Cave Website (implement photo and video galleries, creating virtual tours and enabling online ticket purchase);

- Creating quality marketing strategies and improving social media promotion;

- Organizing quality event program to attract more tourists;

- Set conditions for intersectoral connection of all organizations that can influence the growth of speleotourism;

- Organizing conferences, congresses and other types of business travel, and offer a visit to the cave as a complementary activity;

- Attracting potential investors;

- Using the proximity of the border with Serbia and Romania, and attract Serbian and Romanian tourists.

- Share experience with other cave management structures in the region.

These measures should enable faster and more efficient development of speleotourism, which could be an indicator of local economic growth. Prerequisites for the implementation of these measures should be a well-organized management structure that could adequately present ideas to potential investors and local authorities. After the successful presentation, the realization of the project follows, where it is necessary to hire experts from various scientific fields, researchers, educators and volunteers. It is necessary to involve all stakeholders, as well as the local community in decision-making processes. With this approach, it is possible to achieve a much higher quality speleotourism product and thus modernize and improve speleotourism in this area. 
Considering that karst areas are particularly fragile (van Beynen, 2011), appropriate karst management should be applied. Due to the negative impacts that tourists can have on caves, intentional or unintentional, the management must act in a meaningful and organized manner for the preservation of the cave's geomorphological values. Furthermore, all existing tourist resort developments should be encouraged to reduce the environmental impact of their operation and to upgrade the quality of accommodation and visitor services offered (Hamilton-Smith, 1998). In the case of Magura Cave, the management needs to continue developing speleotourism according to sustainable concepts and geoethical values. Given the relatively low number of visits, it is not necessary to take urgent measures to protect the cave and limit visitations. However, it is necessary to spread awareness and educate visitors about the rules of conduct inside the cave, as well as to invest in adequate security systems that will protect this geosite.

\section{CONCLUSION}

The analysis of the tourist traffic of Magura Cave in northwestern Bulgaria provided an insight into the current state and possible perspectives of the future speleotourism development. The theoretical framework of the paper indicates the importance of speleological geoheritage, as a crucial resource not only for speleotourism, but for geotourism as well. Therefore, it is necessary to carefully consider the ways of karst management and tourism development, taking into account sustainable and geoethical values.

The data on the tourist traffic of the Magura Cave indicate an underdeveloped speleotourism geosite which has exceptional potentials for development. It can be said that this cave belongs to the level of recognition in the tourist market, but it does not have a competitive identity. The data of tourist visits clearly show that the tourism of Magura cave is strictly seasonal, which is expected, taking into account the natural environment of the site itself. Management needs to work on creative ideas on how to extend the tourist season. The results of the research present measures for the sustainable development of speleotourism and the attraction of foreign tourists, which are extremely important for the management of the cave. Also, it is very important that travel agencies and other interest groups place greater focus on the receptive tourism model, thus promote and enhance the development of speleotourism in this area. 


\section{REFERENCES}

Antić, A., \& Tomić, N. (2019). Assessing the speleotourism potential together with archaeological and palaeontological heritage in Risovača cave (central Serbia). Acta Geoturistica, 10, 1, 1-11.

Antić, A., Tomić, N., \& Marković, S. (2019). Karst geoheritage and geotourism potential in the Pek River lower basin (Eastern Serbia). Geographica Pannonica, 23, 1, 32-46.

Avgeli, V., Soteriades, M., Sakoualou, A., \& Fortune, N. (2019). Wine Tourism in Santorini, Crete: Exploring the Behaviour, Motives, and Intentions of Wine Tourists. Journal of Tourism and Hospitality Management, 7, 2, 45-60.

Cahill, K. L., Marion, J. L., \& Lawson, S. R. (2008). Exploring visitor acceptability for hardening trails to sustain visitation and minimise impacts. Journal of Sustainable Tourism, 16, 2, 232-245.

Cigna, A. A., \& Burri, E. (2000). Development, management and economy of show caves. International Journal of Speleology, 29, 1, 1.

Cigna, A. A. (2016). Tourism and show caves. Zeitschrift für Geomorphologie, Supplementary Issues, 60, 2, 217-233.

Cigna, A. A. (2019). Show caves. In Encyclopedia of caves (pp. 909-921). Academic Press.

Dzhambazov, N., Katincharov, R., 1961. Archaeological finds from Magura cave. Archaeology III 3, 56e64 (in Bulgarian).

Escorihuela, J., \& Dowling, R. K. (2015). Analysis of the geotouristic activity in the geologic park of Aliaga, Spain: Progress, threats and challenges for the future. Geoheritage, 7, 3, 299-306.

El Wartiti M, Malaki A, Zahraoui M, Di Gregorio F, De Waele J. 2009. Geosites and touristic development of the north-western Tabular Middle Atlas of Morocco. In Proceedings of Desertification and Risk Analysis Using High and Medium Resolution Satellite Data, Marini A (ed.). Springer Netherlands: Toze ur Tunesia; 143-159.

Farsani, N. T., Coelho, C., \& Costa, C. (2011). Geotourism and geoparks as novel strategies for socio-economic development in rural areas. International Journal of Tourism Research, 13, 1, 68-81.

Filkov, L., 1936/7. Burial in Magura Cave. Nature and Science VII (4), 57e58 (in Bulgarian).

Gordon, J. E. (2018). Geoheritage, geotourism and the cultural landscape: Enhancing the visitor experience and promoting geoconservation. Geosciences, 8, 4, 136.

Hamilton-Smith, E., Kiernan, K., \& Spate, A. (1998). Karst management considerations for the Cape Range karst province, Western Australia. A report prepared for the Department of Environmental Protection.

Ivanova, S., Gurova, M., Spassov, N., Hristova, L., Tzankov, N., Popov, V., ... \& Lewis, M. (2016). Magura Cave, Bulgaria: a multidisciplinary study of Late Pleistocene human palaeoenvironment in the Balkans. Quaternary International, 415, 86-108.

Joo, D., Cho, H., \& Woosnam, K. M. (2019). Exploring tourists' perceptions of tourism impacts. Tourism Management Perspectives, 31, 231-235. 
Köroğlu, F., \& Kandemir, R. (2019). Vulnerable Geosites of Çayırbağı-Çalköy (DüzköyTrabzon) in the Eastern Black Sea Region of NE Turkey and Their Geotourism Potential. Geoheritage, 11, 3, 1101-1111.

Kim, S. S., Kim, M., Park, J., \& Guo, Y. (2008). Cave tourism: Tourists' characteristics, motivations to visit, and the segmentation of their behavior. Asia Pacific Journal of Tourism Research, 13, 3, 299-318.

Lobo, H. A. S. (2015). Tourist carrying capacity of Santana cave (PETAR-SP, Brazil): a new method based on a critical atmospheric parameter. Tourism Management Perspectives, 16, 67-75.

Mikov, V., 1927. Magura Cave. In: Bulgarian Tourist, vol. IX, pp. 9e12 (in Bulgarian).

Pellešová, P. (2020). Globalization and perception of tourism trends by supply and demand. In SHS Web of Conferences (Vol. 74, p. 04019). EDP Sciences.

Rogerson, C. M. (2020). In Search of Inclusive Tourism in South Africa: Some Lessons from the International Experience. In New Directions in South African Tourism Geographies (pp. 147-165). Springer, Cham.

Rivero, M. S., Rangel, M. C. R., \& Martín, J. M. S. (2019). Geotourist Profile Identification Using Binary Logit Modeling: Application to the Villuercas-Ibores-Jara Geopark (Spain). Geoheritage, 11, 4, 1399-1412.

Ríos-Reyes, C. A., Chaparro, J. E. G., Ruiz, J. I. H., Otero, D. Z., Rangel, D. S. B., \& Carreño, J. C. D. (2018). Geotouristic potential in karst systems of santander Colombia the begining of right geoducational and geoconservational practices. International Journal of Hydrology, 2, 2.

Schliephack, J., \& Dickinson, J. E. (2017). Tourists' representations of coastal managed realignment as a climate change adaptation strategy. Tourism Management, 59, 182192.

Stoytchev, T., 1994. Horse Painting from Magoura Cave. In: Bulgaria Annual of Department of Archaeology - NBU, vol. I (Sofia).

Tičar, J., Tomić, N., Valjavec, M. B., Zorn, M., Marković, S. B., \& Gavrilov, M. B. (2018). Speleotourism in Slovenia: balancing between mass tourism and geoheritage protection. Open Geosciences, 10, 1, 344-357.

Tomić, N., Antić, A., Marković, S. B., Đorđević, T., Zorn, M., \& Valjavec, M. B. (2019). Exploring the Potential for Speleotourism Development in Eastern Serbia. Geoheritage, 11, 2, 359-369.

Uvalić, M. (2001). Regional cooperation in Southeast Europe. Southeast European and Black Sea Studies, 1, 1, 55-75.

van Beynen, P. E. (Ed.). (2011). Karst management. Springer Science \& Business Media. Vespestad, M. K., Lindberg, F., \& Mossberg, L. (2019). Value in tourist experiences: How nature-based experiential styles influence value in climbing. Tourist Studies, 19, 4, 453-474.

Vukoičić, D., Ivanović, R., Radovanović, D., Dragojlović, J., Martić-Bursać, N., Ivanović, M., \& Ristić, D. (2020). Assessment of Geotourism Values and Ecological Status of Mines in Kopaonik Mountain (Serbia). Minerals, 10, 3, 269. 
Wong, I. A., \& Zhao, W. M. (2016). Exploring the effect of geographic convenience on repeat visitation and tourist spending: The moderating role of novelty seeking. Current Issues in Tourism, 19, 8, 824-844.

Štrba, L., Kolačkovská, J., Kudelas, D., Kršák, B., \& Sidor, C. (2020). Geoheritage and Geotourism Contribution to Tourism Development in Protected Areas of SlovakiaTheoretical Considerations. Sustainability, 12, 7, 2979.

\section{CONFLICTS OF INTEREST}

The author declared no potential conflicts of interest with respect to the research, authorship, and/or publication of this article.

(C) 2020 by the author. This article is an open access article distributed under the terms and conditions of the Creative Commons Attribution (CC BY) license (http://creativecommons.org/licenses/by/4.0/). 